\title{
É CERTO QUE RISTE: HUMOR NO CRISTIANISMO
}

\author{
Salma Ferraz \\ "Então, Sara, receosa, o negou, dizendo: Não me ri. Ele, \\ porém, disse: Não é assim, é certo que riste” \\ Gênesis 18:15
}

\section{POR QUE DEUS É HUMOR}

Em verdade em verdade vos digo que eu gostaria de usar como título deste artigo Por Deus é Humor, mas a mentira me condenará (não quero ser chamada de vaca de Basã) e a verdade me libertará, não pude roubar esta genialidade que é o nome do site, cujo domínio pertence ao humorista e Pastor Jasiel Botelho, Missionário da Sepal e Professor de Teologia da FLAM. Sigamos, por que Deus é Humor!

To be, or not to be: that is the question, já afirmava Shakespeare num parte de Hamlet. Homo ludens ou homo rides eis outra questão que nos interessa neste momento.

A serpente enganou Eva, que enganou a Adão que acusou Eva que acusou a Serpente. Sara riu da promessa de YHVH lhe dar ao filho na sua velhice. Jacó enganou a Isaac, roubou a primogenitura de ser irmão Esaú e se fez passar por ele perante o seu pai. Mais tarde Jacó é enganado por Labão que lhe dá como esposa Lia no lugar da amada Raquel. As matriarcas disputam a atenção sexual do Patriarca colhendo Mandrágoras, uma espécie de Viagra da época. O Patriarca também é enganado por seus filhos, liderados por Judá que vendem José como escravo para mercadores 
do Egito. José do Egito engana seus irmãos ao não se revelar para eles. Judá engana sua nora Tamar ao não dar seu terceiro filho como esposo para esta, desrespeitando a lei do Levirato. Tamar por sua vez engana a seu sogro e agora viúvo Judá, disfarçando-se por uma meretriz e tendo um filho dele, o que vai lhe garantir sua descendência. Se o Gênesis pudesse ser resumido numa charges, esta seria:

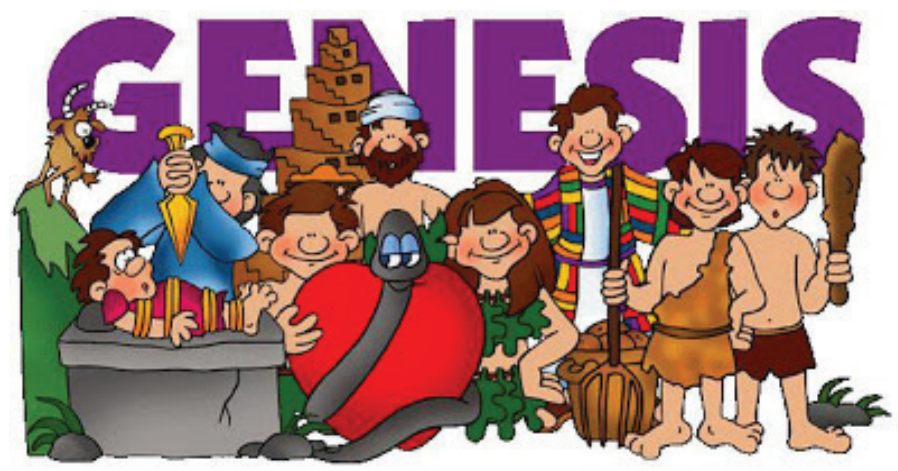

Site Resposta Cristã

\section{O RISO E OS CRÍTICOS}

Todos estes enredos rocambolescos no Velho Testamento servem para responder seguinte pergunta: Há humor na Bíblia? Sim, e há muito humor. Robert Alter em A arte da Narrativa Bíblica (2007) aponta as repetições e cenas padrão, ciclo do enganador-enganado presente no Gênesis. Este livro é repleto de ironia e maquinação em seu conteúdo.

Um outro excelente estudo sobre o riso, é o capítulo A Diabolização do Riso na Ata Idade Média do livro História do Riso e do Escárnio de Georges Minois (2003). Na introdução do livro o crítico nos alerta que o riso tem um lado revolucionário e subversivo, que é ambivalente, multiforme, ambíguo, que o humor não tem idade nem pátria, que flutua no equívoco e na indeterminação. Segundo o crítico “... o riso está a cavalo sobre uma dupla verdade. Serve ao mesmo tempo para afirmar e subverter." (2003, p. 16, negrito nosso). Afirma ainda que o riso se encontra na encruzilhada do divino e do diabólico. Cita J. Lederer para quem o riso é uma espécie de soluço invertido, já que rimos porque somos o único animal que sabe que vai morrer.

"Se o riso é qualificado às vezes como diabólico, é porque ele pôde passar por um verdadeiro insulto à criação divina, uma espécie de vingança do diabo, uma manifestação de desprezo, de orgulho, de agressividade, de regozijo com o mal." (2003, p. 19) 
No capítulo citado, Minois faz um estudo rico e aprofundado do riso do Velho e Novo Testamento. Na primeira parte engana o leitor ao fazer as seguintes afirmações e perguntas: o riso não é natural no Cristianismo, Deus se basta, não é preciso rir de nada, como poderia haver riso na Trindade, imutável, sem corpo e sem sexo, eternamente absorvida em sua autocontemplação? Afirma que o Gênese é solene, que no Éden não havia lugar para riso, que a história santa é seria por excelência, que não se deve brincar com a história da salvação da humanidade, porque o riso não fazia parte do plano divino, nem a Bíblia tem intenção cômica. O único motivo de riso é o homem, criatura decaída:

Há de quê: rir do outro, desse fantoche ridículo, nu, que tem um sexo, que peida e arrota, que defeca, que se fere, que cai, que se engana, que se prejudica, que se torna feio, que envelhece e que morre - um ser humano, bolas! Uma criatura decaída. O riso vai se insinuar por todas as imperfeições humanas. É uma constatação de decadência e, ao mesmo tempo, um consolo, uma conduta de compensação, para escapar ao desespero e à angústia: rir para não chorar. (...) Vemos nosso nada e rimos dele; um riso diabólico. (2003, p. 112, negrito nosso)

O riso estaria ligado à imperfeição humana. Afirmei acima que o crítico engana o leitor. Na segunda parte deste capítulo ele afirma "É claro que há riso na Bíblia" (2003, p. 115). E isto ocorre justamente pela "extraordinária flexibilidade da Bíblia, com a qual se pode fazer qualquer coisa” (2003, p. 115). A partir daí desenvolve o que denomina de Evolução do cômico na Bíblia, passando pelo estilo dos autores bíblicos que contrapõem o sublime com o trivial, o cômico com o trágico, aponta Jacó como um anti-herói imoral e sua vida como uma comédia picaresca, passa pelo episódio de Elias contra os 450 profetas de Baal até chegar à questão muito discutida pelos pais da Igreja pelos pais do Deserto se Jesus riu ou não riu?

Para Minois no Velho Testamento o tom é mais grave. Todo ele é mais severo com relação ao riso: Paulo e Tiago condenam o riso. No geral, o Novo Testamento condena o riso. Como não se fala que Jesus riu, os cristãos deveriam imitar seu exemplo. Quantas consequências negativas advirão desta constatação! O riso é mais negativo no Novo Testamento que no Velho Testamento. No Novo Testamento dos cristãos, o riso aparece como escarnecimento da vontade de Deus. O Judaísmo manteve o humor do Velho Testamento, já o Cristianismo não recebeu esta herança. Segundo o crítico, a encarnação e a redenção desafiam toda e qualquer lógica humana racional, por isto não há riso ali. $\mathrm{O}$ gênero por excelência do Cristianismo é o drama, não sobre espaço para o riso. Já nos Apócrifos tanto Deus como Jesus riem. Depois analisa o humor entre os pais da Igreja e os pais do Deserto. Termina este capítulo com a seguinte afirmação: 
Mas o homem se salva pelo amor ou pelo humor? As duas noções são tão estranhas uma à outra? O fiel de base que parodia o culto a Bíblia, que treme e que ri de Deus e do diabo, não estará, inconscientemente, mais perto da verdade - ou da ausência da verdade? (2003, p. 154)

Henri Bergson em seu livro O Riso: ensaio sobre a significação do Cômico afirma que não há comicidade fora do humano, porque se o homem já foi definido como o único animal que ri, ele também é o único que faz rir, já que precisamos de um grupo para rir de nossas piadas. Segundo o autor não há comicidade na solidão, neste ponto o riso possui um função social. Aponta ainda que o cômico dirige-se sempre para a inteligência pura e não há compatibilidade entre o riso e a emoção.

Em seu livro Ironia e Humor na Literatura, Lélia Parreira Duarte reafirma a noção antiga de que o homem é o único animal que ri e ri porque sabe que é mortal. Segunda ela o riso possui o paradoxo intrínseco de ao mesmo tempo revelar alegria e tristeza. Para a crítica o riso ajuda a suportar o trágico da existência humana, já que o homem sabe que é um ser para a morte. Por mais que o riso dure um instante, naquele breve momento o homem é superior ao humano, tem a impressão de ser imortal, torna-se igual aos deuses, ri de si e dos outros, afirmando seu poder sobre o outro. O ser humano ri porque não se conforma com a descontinuidade da vida, porque é inconformado, e rindo, esquece que é mortal. O ser precário e mortal, torna-se quase um Deus quando ri, esquecendo-se que caminha para a morte. Segundo Duarte:

O riso revela-se útil, assim, para a manutenção da espécie: experiência do nãosaber, livra do desespero do

pensamento aprisionado nos limites do sério. Nesse sentido, saber rir é momentaneamente tornar-se "Deus", experimentar o impensável, sair da finitude da existência (...) Dada a relação entre o riso e a morte, o autor literário cômico será portanto um autor funéreo. (2006, p.53-54, negrito nosso)

A autora afirma também que talvez a única salvação possível e utópica para o homem seja o riso, porque quando ri, o homem jubila e se regozija perante o absurdo que é a morte.

Já Concetta d'Angeli e Guido Paduano em sua obra O Cômico enfatizam o caráter moralizante do cômico: Castigat ridendo mores. É por meio do riso que de denunciamos os vícios e se preparamos sua repreensão e correção. Para estes estudiosos o cômico recupera o prazer pedido na infância. O riso é uma arma poderosa contra a moral, a razão e a morte. Não rimos da morte, mas rimos porque sabemos que somos mortais. 


\section{JESUS ESBOÇA UM SORRISO E FINALMENTE RI}

Seguindo na esteira das colocações de Minois sobre o grande debate que permeou as discussões dos primeiros pais da Igreja e pais do Deserto e se estendeu pela Idade Média, se Jesus riu ou não, o Ocidente cultuou a imagem de Jesus durante quase dois mil anos, sem um sorriso na face. Observemos um detalhe da imagem Cristo Yacente, do escultor representante do Barroco espanhol Gregório Fernandes (1576-1636)

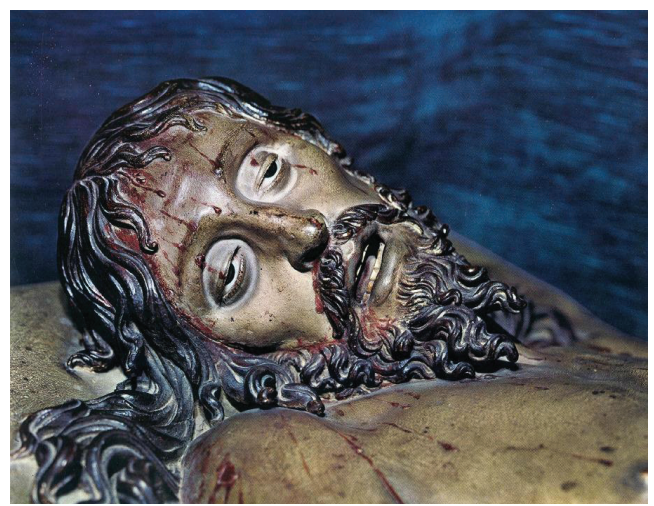

Cristo Yacente. Gregório Fernandes

O Cristo barroco sempre é apresentado em agonia, êxtase e morto. Foram quase dois mil de pinturas e esculturas que mostravam apenas sofrimento. É difícil localizar exatamente se foram os Protestantes ou Católicos quem primeiro representaram Jesus como bom Pastor com ameaça de sorriso no rosto:
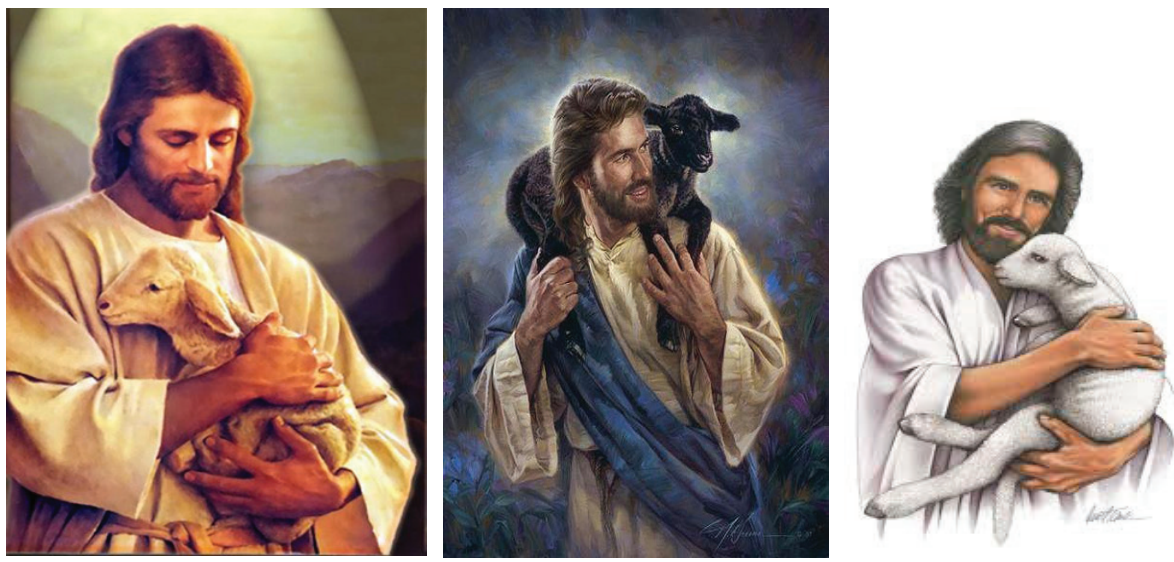


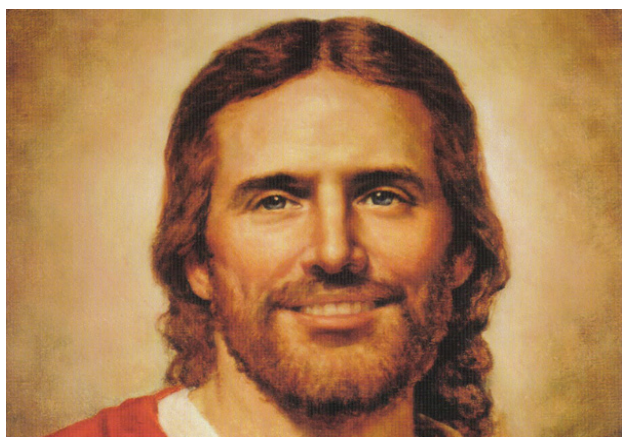

Como se pode observar esta ameaça de sorriso foi se expandido ao longo das décadas até a última imagem em que aparecem os dentes de Jesus. Alguns Pais da Igreja como São João Crisóstomo (344-407), e São Basílio (330-379), ferrenhos inimigos do riso cairiam duros ao ver as imagens de Jesus acima. Cabe aqui citar um grupo de cristãos intitulados Ministros do Riso, fundado em 2006 por Alex Rangel, que prega o evangelho por meio de danças, encenações, piadas, apresentado a mensagem de Jesus de uma forma lúdica. Em tempos de Internet, a representação de Jesus evolui para o Jesus meio zombador e crítico que questiona o fato dos cristãos não riem:

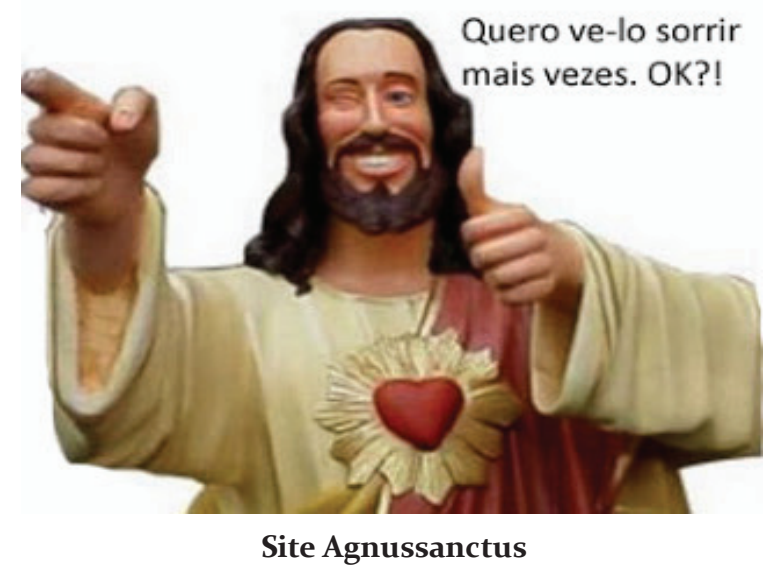

\section{O VELHO HUMOR DO VELHO TESTAMENTO}

Posto e afirmado que há riso na Bíblia e com a presença iluminadora dos Ministros do Riso, citemos quatro exemplos mais contundentes do Velho Testamento. Primeiro os rapazinhos aborrecentes que zombavam de Eliseu o chamando de careca. Usaremos a Versão Nova Tradução na Linguagem de Hoje (NTLH): 
Eliseu saiu de Jericó para ir a Betel. Ele ia andando pela estrada, quando alguns rapazes saíram de uma cidade e começaram a caçoar dele, gritando assim: - Ó seu careca, fora daqui!

Eliseu virou para trás, olhou firme para os rapazes e os amaldiçoou em nome de Deus, o SENHOR. Então duas ursas saíram do mato e despedaçaram quarenta e dois deles. (2 Reis 2:23-24, negrito nosso)

Este episódio, não tanto pelo humor dos aborrecentes rebeldes, mas pelo conteúdo violento da estória, é assim criticado nas charges da Internet:
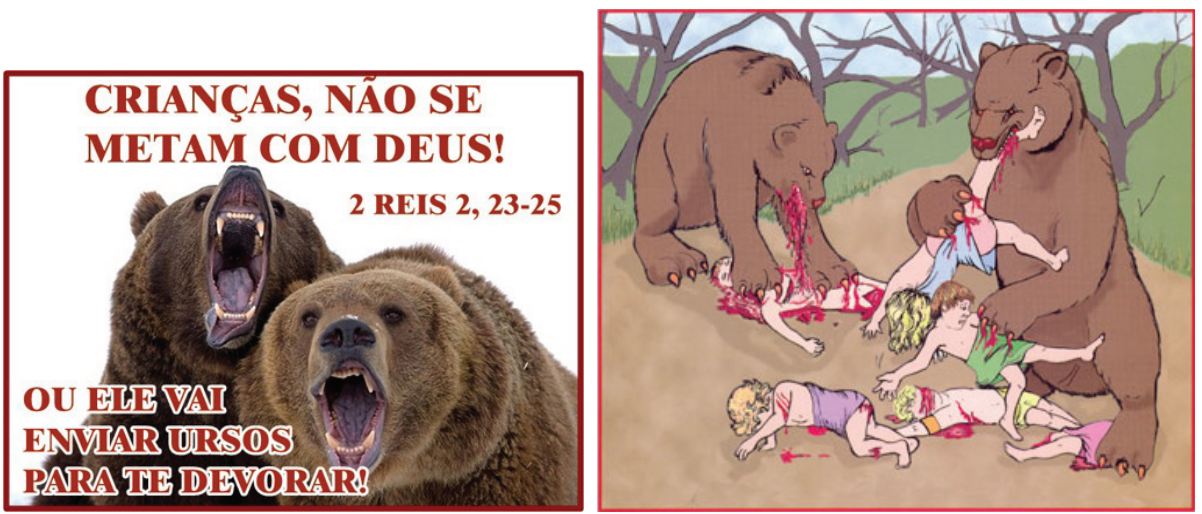

Site verdades inconvenientes

Como se constata não se pode rir de um profeta de Deus. As crianças são assassinadas por um motivo aparentemente fútil: porque riram de Eliseu. Ele segue sua viagem e deixa os cadáveres despedaçados. Há um desenho animado na internet denominado Eliseu o Estúpido profeta careca, que questiona porque nunca mais se fala nas criancinhas da Bíblia Sangrenta. O segundo exemplo é o poderoso Profeta Elias. Observemos Elias em transe, verdadeiramente possesso, gritando, exultando, provocando os 450 profetas de Baal que estavam a serviço de Jezebel:

Ao meio-dia, Elias começou a caçoar deles. Ele dizia: - Orem mais alto, pois ele é deus! Pode ser que esteja meditando ou que tenha ido ao banheiro. Talvez ele tenha viajado ou talvez esteja dormindo, e vocês terão de acordá-lo!

Elias, pulando e dançando afirma que Baal não pode atender porque está defecando. A charge do site Genizah acima fala por si! 


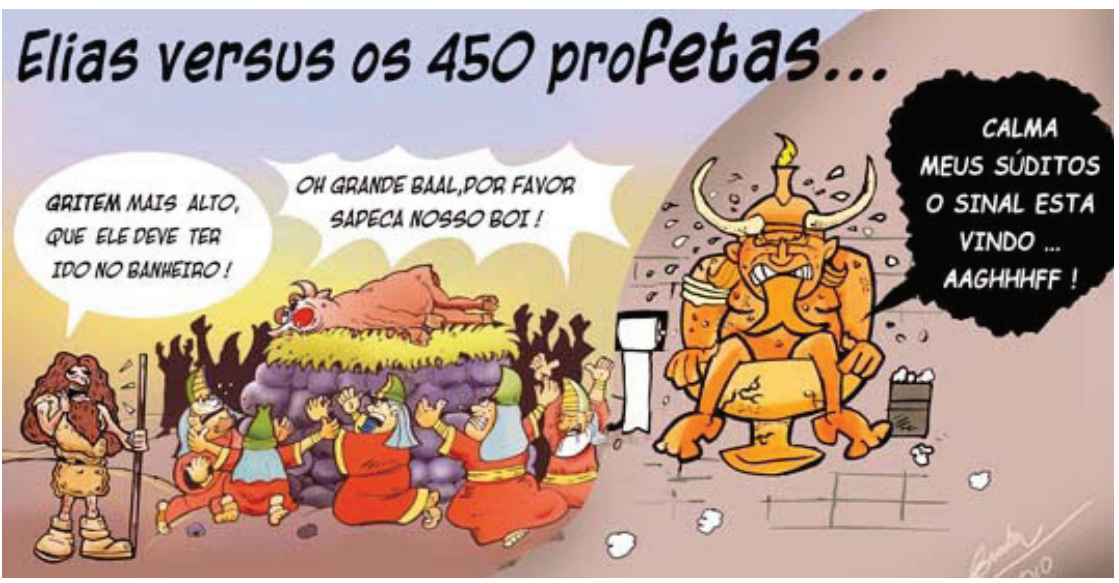

Site Genizah

Ao final, Elias, o grande degola cabeças do Velho Testamento, degola os 450 profetas de Baal. Fora as bofetadas trocadas entre os falsos e verdadeiros profetas citados na Profecia de Micaías em I Reis 22 e Acabe que nomeia sarcasticamente Elias como o epíteto de o Perturbador de Israel.

Como terceiro exemplo de humor, apontamos Jacó, como o mais atrapalhado herói pícaro do Velho Testamento: covarde, medroso, ladrão, indeciso, atrapalhado. Vários sites cristãos o apontam como maior anti-herói bíblico ao lado de Davi. Há uma pesquisa do doutorado em andamento que analisa Jacó como típico pícaro bíblico e que está sendo desenvolvido pelo pesquisador Josué Chaves na UFSC.

A vida do pícaro Jacó é uma verdadeira montanha russa de enganos, trapaças, ciúmes, vingança, orações, promessas e chamados como bem o demonstra o gráfico abaixo:

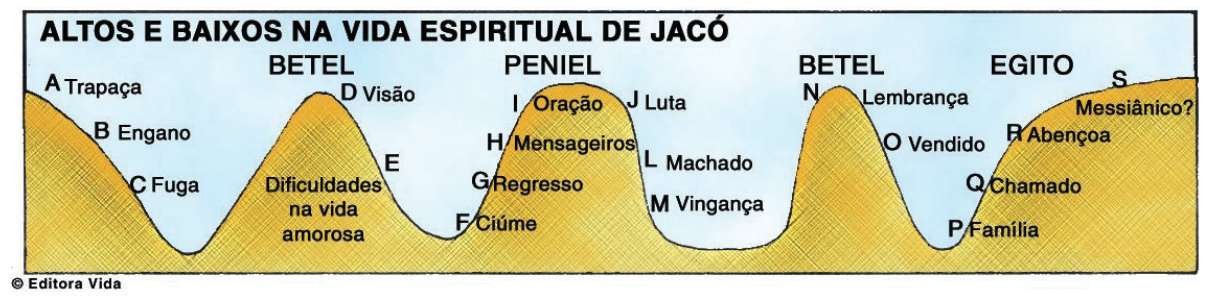

Blog do Antonio Vilmar.

Com esta vida rocambolesca e novelesca, Jacó é um dos preferidos das charges bíblicas. O anti-herói bíblico o pícaro Jacó é retratado como alguém sem dimensão de suas forças, visto que é um faixa vermelha que vai encarar no tatame do Vale de Jaboque, um anjo faixa preta. 


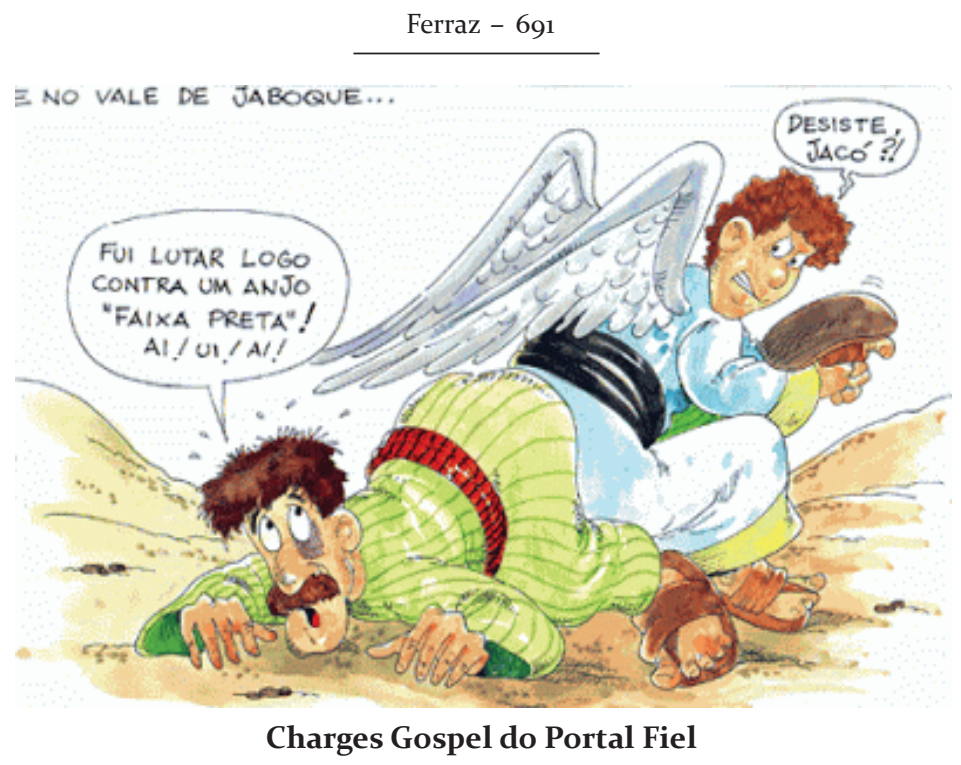

Como quarto exemplo podemos mencionar Jonas, o profeta fujão e medroso, que foi parar dentro da um grande peixe. Esse episódio é um dos mais satirizados nas charges Bíblicas:

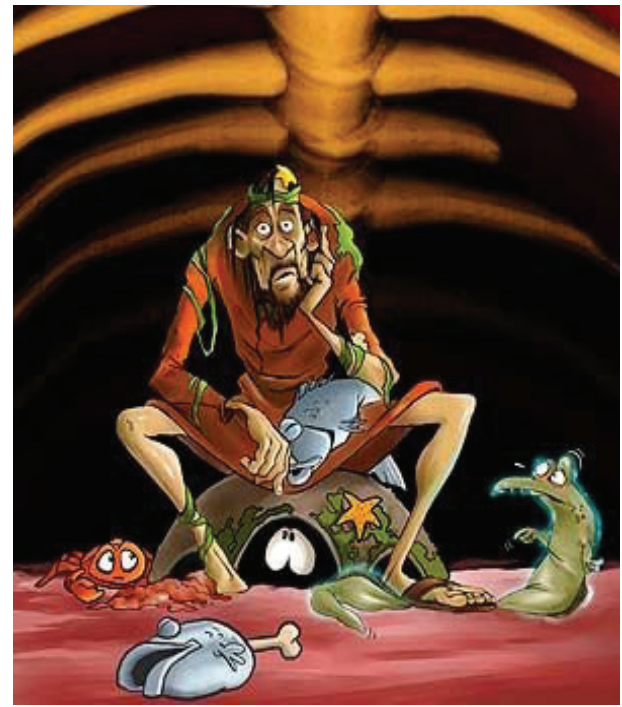

Jonas, o medroso e zangado profeta, Site infiltrados no mundo

Lembremos também a linguagem rústica do profeta-colono Amós, oriundo de Tecoa que cuidava de gado e conduzia boi: "Ouvi esta palavra, vós, vacas de Basã, que estais no monte de Samaria..” (Amós 4:1, negrito nosso). 
692 - Remate de Males 34.2

\section{O NOVO HUMOR NO NOVO TESTAMENTO.}

Mas o riso que é mais caudaloso do Velho Testamento não é exclusividade dos Judeus. No Novo Testamento também há riso. Afinal o que fazia aquele misterioso homem $\mathrm{nu}^{1}$ que aparece seguindo a Jesus no momento trágico de sua prisão no Horto das Oliveiras que aparece em Marcos 14: 51? E o Apóstolo Pedro, medroso e mentiroso com medo do simples cantar de um galo. Observemos agora Atos 19:13

\footnotetext{
"Alguns judeus que andavam de um lugar para outro, expulsando espíritos maus, quiseram usar também o nome do Senhor Jesus para expulsar os espíritos maus, dizendo a eles: - Pelo poder do nome de Jesus, o mesmo que Paulo anuncia, eu mando que vocês saiam!

Os homens que faziam isso eram os sete filhos de um judeu chamado Ceva, que era Grande Sacerdote.

Mas certa vez um espírito mau disse a eles: - Eu conheço Jesus e sei quem é

Paulo. Mas vocês, quem são?

Então o homem que estava dominado pelo espírito mau os atacou e bateu neles com tanta violência, que eles fugiram daquela casa feridos e com as roupas rasgadas." (negrito nosso)
}

O exorcismo não deu certo, visto que demônios frustraram uma tentativa de exorcismo, porque não aceitavam a terceirização do exorcismo. Eles conheciam Jesus, conheciam Paulo, mas afinal quem eram estes filhos de Ceva para excomungá-los? O exorcismo afinal virara uma bagunça, uma farra. Os demônios dão uma surra nos exorcistas.

\section{6 . IGREJA X MOTEL}

Em livro de minha autoria publicado em 2012, pela EDUEL. intitulado As Malasartes e Lúcifer, traço ali um estudo sobre as origens de Lúcifer, a ausência do figura do Demônio no Velho Testamento, sua ínfima participação no sofrimento e tentação de Jó, sua evolução para o Diabo poderoso do Novo Testamento, o Diabo entre o teólogos, o Diabo entre os críticos e por fim o Diabo como magnífico personagem da Literatura Ocidental, a transformação do mesmo em mero ser de papel, inesgotável baú a ser explorado. Interessame sobremaneira o estudo de Isa Gomes da Cunha Chain desenvolvido em seu livro O Diabo nos Porões das Caravelas (2003) no qual retrata a mentalidade, o

${ }^{1}$ Julio de Queiroz explora este pequeno detalhe do Evangelista Marcos e cria um conto surpreendente intitulado Enigma do Entardecer presente no livro Encontro de Abismos, terceira edição publicado pela Insular, Florianópolis em 2007. 
colonialismo e reflexos na constituição da religiosidade brasileira nos séculos XVI e XVII e como a mentalidade lusitana se adaptou à cultura brasileira. Ou seja, como Deus e o Diabo se aclimataram abaixo dos trópicos.

Ao ler esta obra, percebemos que tanto Deus como o Diabo foram aclimatados aos trópicos, perdendo um pouco o poder teológico que gozavam na Europa, antes de entrarem nos porões das caravelas. Tantos um como o outro se abrasileiraram. Basta observarmos a alegria dos brasileiros ao afirmarem que "Deus é brasileiro" e ao utilizarem, com naturalidade, expressões como "este menino é um capeta" ou "é o cão chupando manga", esta última originária do nordeste. Se Deus é brasileiro, o Diabo também é, basta ver as centenas de ápodos, com que mesmo é conhecido em terras brasílicas:

anhanga ou anhangá, anhangüera, arrenegado, azucrim, barzabu, barzabum, beiçudo, belzebu, berzabu, berzabum, berzebu, bicho-preto, bode-preto, brazabum, bute, cafuçu, cafute, caneco, caneta, canheta, canhim, canhoto, cão, cão-miúdo, cão-tinhoso, capa-verde, capeta, capete, capiroto, careca, carocho, chavelhudo, cifé, coisa, coisa-à-toa, coisa-má, coisa-ruim, condenado, coxo, cramulhano, cujo, debo, decho, demo, demonho, demônio, demontre, diá, diabinho, diabrete, diabro, diacho, diale, dialho, diangas, diangras, dianho, diasco, diogo, dragão, droga, dubá, éblis, ele, excomungado, farrapeiro, fate, feio, figura, fioto, fute, futrico, galhardo, gato-preto, grão-tinhoso, guedelha, indivíduo, inimigo, jeropari, jurupari, labrego, lá-de-baixo, lúcifer, macacão, macaco, mafarrico, maioral, má-jeira, maldito, mal-encarado, maligno, malino, malvado, manfarrico, mau, mico, mofento, mofino, satã, satanás, satânico, serpente, sujo, taneco, temba, tendeiro, tentação, tentador, tição, tinhoso, tisnado, zarapelho.

moleque, moleque-do-surrão, não-sei-que-diga, nem-sei-que-diga, nico, pécascudo, pé-de-cabra, pé-de-gancho, pé-de-pato, pé-de-peia, pêro-botelho, pedro-botelho, peneireiro, porco, porco-sujo, provinco, que-diga, rabão, rabudo, rapaz, romãozinho, sapucaio, sarnento, etc

Sóa título deexemplopoderíamos citarobras consagradas na literatura brasileira nas quais o Diabo apronta das suas: O Sermão do Diabo (1893) e a Igreja do Diabo (1899) de Machado de Assis, O Bom Diabo (1937) incluído no Livro Histórias de Tia Nastácia) de Monteiro Lobato, Belzebu.com (1969, incluído no livro Orgias), Alma Vendo de Luis Fernando Veríssimo e Eu e Bebu na hora neutra da Madrugada (1998, incluído no livro 200 Crônicas Escolhidas) de Rubem Braga. Isto sem mencionar as centenas de histórias infantis clássicas e brasileiras em que o Diabo é enganado e sua absoluta relevância na literatura de Cordel do Nordeste Brasileiro² ${ }^{2}$. Sobre

${ }^{2}$ Estela Ramos de Souza estudou este assunto em sua dissertação de Mestrado intitulada O Diabo ridicularizado na literatura de Folhetos do Nordeste, defendida na UFSC em Abril de 2013. 
o Diabo no Cinema Brasileiro há uma excelente dissertação de mestrado intitulada O Diabo também é brasileiro: a figura de Satanás no Cinema Nacional de Felipe de Monte Guerra defendida em 2011, na Universidade Anhembi de São Paulo. Também não mencionaremos todas as obras da Literatura Ocidental no qual o Diabo/Lúcifer é protagonista. A título de exemplo citamos apenas três clássicos: O Paraíso Perdido (1667) de Milton, Grande Sertão: Veredas (1956) de Guimarães Rosa e O Evangelho Segundo Jesus Cristo (1991) de José Saramago.

Na internet, o Diabo é satirizado de diversas maneiras. Como há muitos programa de TV que elegem os TOP 5 , do dinheiro, da beleza e da moda, o Diabo, figura tão popular e quase querida no Brasil, ganhou o seu. Observemos o TOP 5 fatos sobre o Capeta.

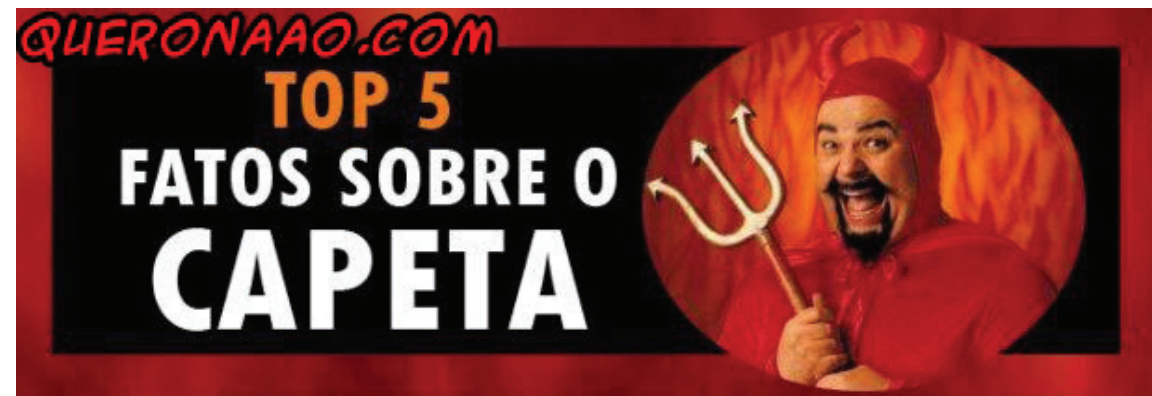

1 - PODERIA ENTRAR EM QUALQUER UM, INCIUSIVE NO OBAMA E DAR INÍCIO A $3^{\circ}$ GUERRA MUNDIAL, MAS PREFERE SE DEDICAR A ARRUINAR A VIDA DOS CRENTES.

2 - JAMAIS ENCARNA EM ATEUS OU ADEPTOS DE OUTRAS REIIGIÕES COMO BUDISTAS OU HINDUS. CURIOSAMENTE, SÓ BAIXA EM CRISTÃOS QUE ACREDITAM NELE.

3 - SÓ GOSTA DE POBRES: VOCÊ JAMAIS VAI VER UM RICO POSSUIDO NUMA IGREJA EVANGÉLICA OU UM PAI DE SANTO MILIONÁRIO.

4- SE VOCÊ GOSTA DE ROCK, PROVAVELMENTE ALGUÉM JÁ ACHOU QUE EIE ESTAVA EM VOCE.

5 - DIZEM QUE É A CAUSA DE TODOS OS SEUS PROBLEMAS. SE VOCÊ TEM DOENÇAS, ESTÁ DEPRIMIDO, DESEMPREGADO, BEBE, FUMA, USA DROGAS, ESTÁ SOFRENDO, VÊ VULTOS, OUVE VOZES OU TEM QUALQUER OUTRO PROBLEMA NA VIDA, CERTAMENTE VOCE DEVE IR AGORA MESMO PARA UMA IGREJA POIS ESTÁ COM UM ENCOSTO! 
O que é criticado aqui é o suposto orgulho ignorante de alguns cristãos fudnamentalistsa que se acham tão importante, que forças cósmicas lutam por suas preciosas almas, e que podem ser possuído, a torta e à direita, pelo Diabo em pessoa, como se este não tivesse mais que fazer... Afinal por quê o Diabo gosta tanto de pobre e crente? Algum ateu já foi possuído pelo Diabo? E afinal o que faz mais sucesso o Diabo ou Jesus? Ajustando a pergunta, em qual lugar mais se pronuncia o nome de Jesus numa Igreja ou num Motel. Observemos o cartaz abaixo:

\section{PALAVRAS MAIS PRONUNCIADAS:}

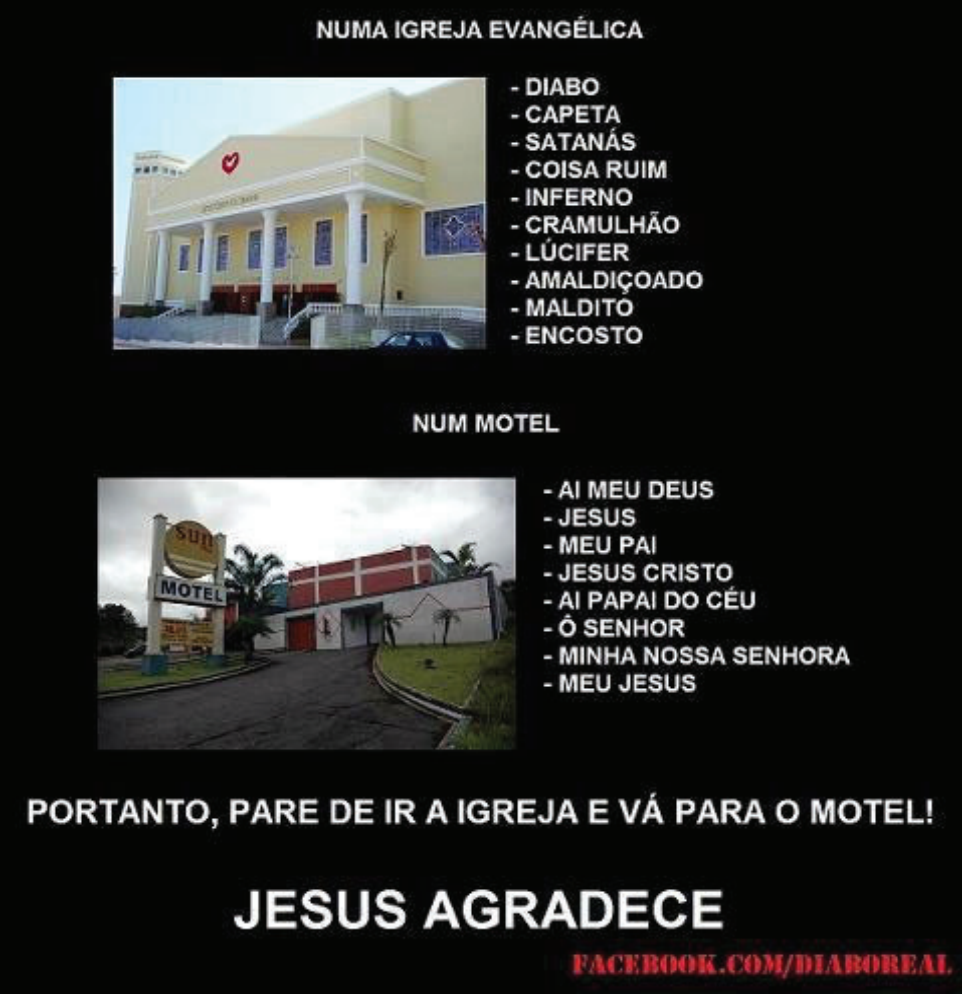

O cartaz acima possui um humor realista e crítico: o nome do Diabo é muito pronunciado em cultos de cura e milagres, principalmente entre evangélicos e pentecostais em que se expulsa os demônios. Estes rituais são televisionados e os telepastores realizam midiaticamente exorcismos num frenesi enlouquecedor. Já num Motel haveria um clima mais tranquilo que a Igreja. No Motel o cristão estaria mais em comunhão com o sagrado que dentro de uma Igreja barulhenta na qual o capeta, Diabo e Satanás são invocados ao som de gritos e urros. 
Aliás, o próprio e querido Pato Donald é usado para questionar o dom de falar em línguas dos pentecostais.

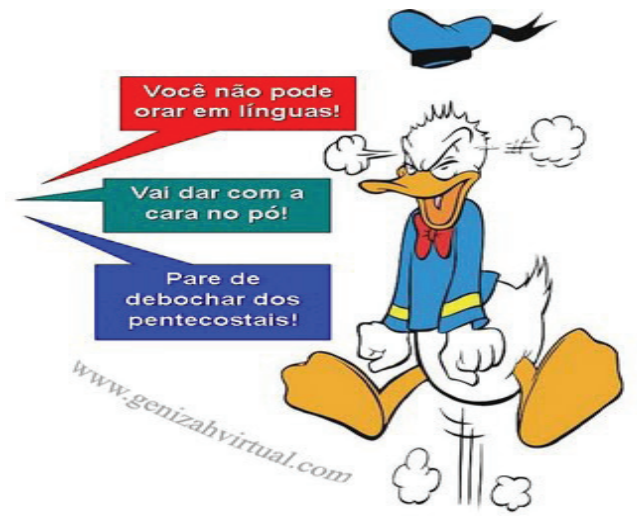

Este site denominado Genizah, tem a seguinte chamada: "Apologética, blogosfera cristã, humor como ferramenta de subversão, humor e cristianismo, reforma protestante, capelania na internet, falsos profetas e muito mais!" (BRIZOTTI, 2013, p. 1). Uma outra chamada do site explica que o site continuará enquanto houver macumba, gospel, profeta e herege. Sua eternidade está garantida! A charge acima criticando os pentecostais foi postada em 2009 e gerou certos comentários que a revidavam. O autor da charge Alan Brizotti se defendeu das críticas recebeu citando o poeta italiano Luciano Folgore (1888-1966) para quem "O humorismo é a arte de virar no avesso, repentinamente, o manto da aparência para por à mostra o forro da verdade" (Idem, p. 1). Os habitantes de pentecópolis poderiam ficar sem esta... No judaísmo todos sonhavam com a canapólis, depois com o advento do messias passaram a sonharam com jerusópolis, cidade esta que se proliferou em catópolis, pentecópolis e cariscópolis. Quanto aos ateus, também eles tem o seu infernópolis! Há lugar para todo o propósito debaixo do sol.!

\section{AS CHARGES BÍBLICAS}

Casou-me certo espanto o número de sites de charges cristãs bíblicas na internet (sites, blogs, orkut, facebook). Só de sites localizei e pesquisei em torno de 30. A dificuldade, assim como nos folhetos de cordéis do Nordeste, é identificar ao certo a autoria das charges, porque elas se multiplicam, umas trazem autoria, em outras a mesma charge aparece sem autoria, em outros sites ela aparece com uma pequena modificação. A autoria aqui não é nossa principal preocupação, porque daria um estudo 
aprofundado de mestrado. Em muitos sites que trazem charges cristãs, o próprio Jesus parece curtindo o site, como no blog do Chargista cristão Leonardo Nicolau, intitulado Só risos abençoados.

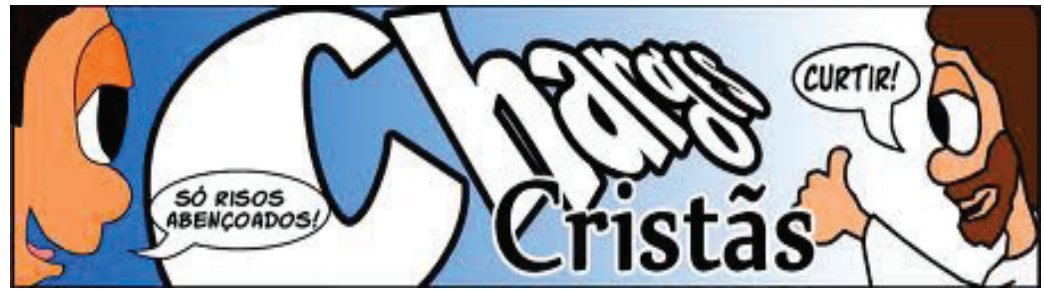

Deste blog retiramos uma atualização feita pelo chargista das cartas do Apóstolo Paulo aos Coríntios:
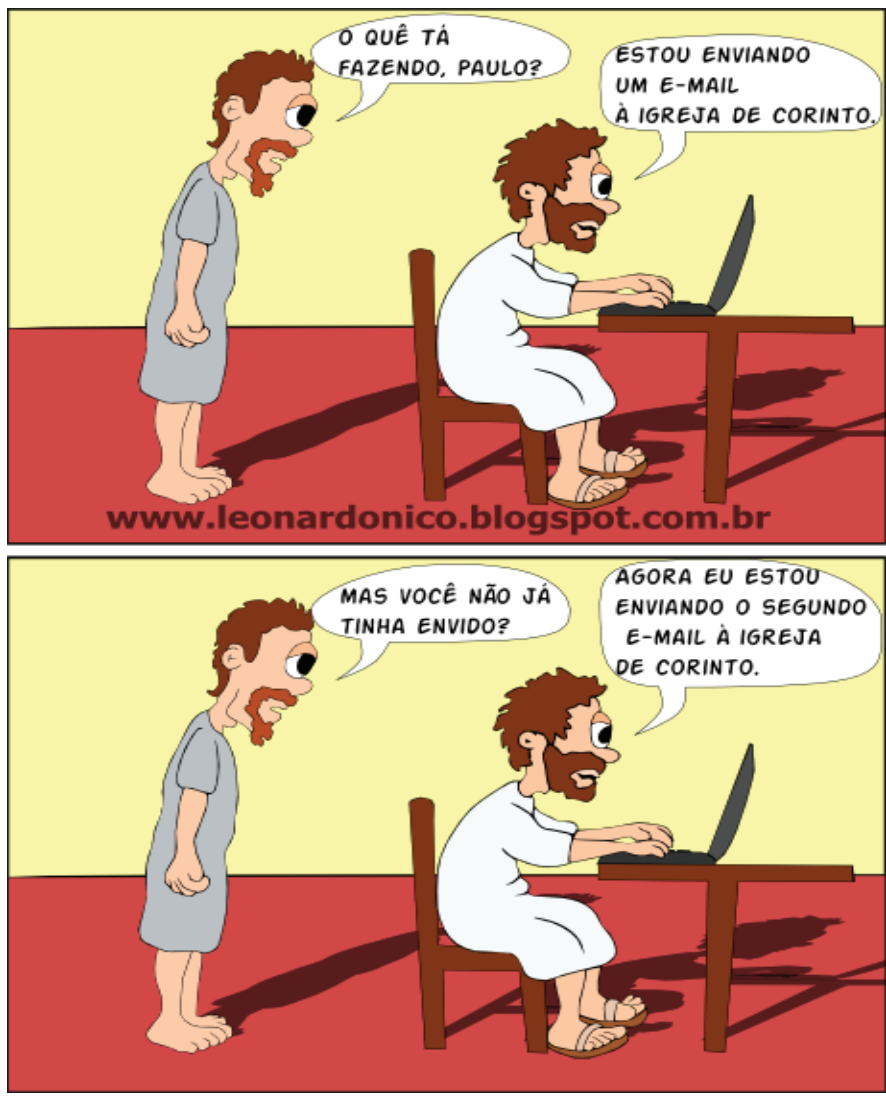

Site Só Risos Abençoados!

Se houvesse internet e email naquela época, Paulo não precisaria ter sofrido tanto com longas viagens, perseguições, tempestades e até o tufão Eroquilão e naufrágio no Mar Adriático, a caminho para Itália, no qual a 
popa do navio se abriu pela violência do mar e os passageiros, inclusive Paulo, tiveram que se lançar ao mar. E muito menos o anjo da guarda do Apóstolo:

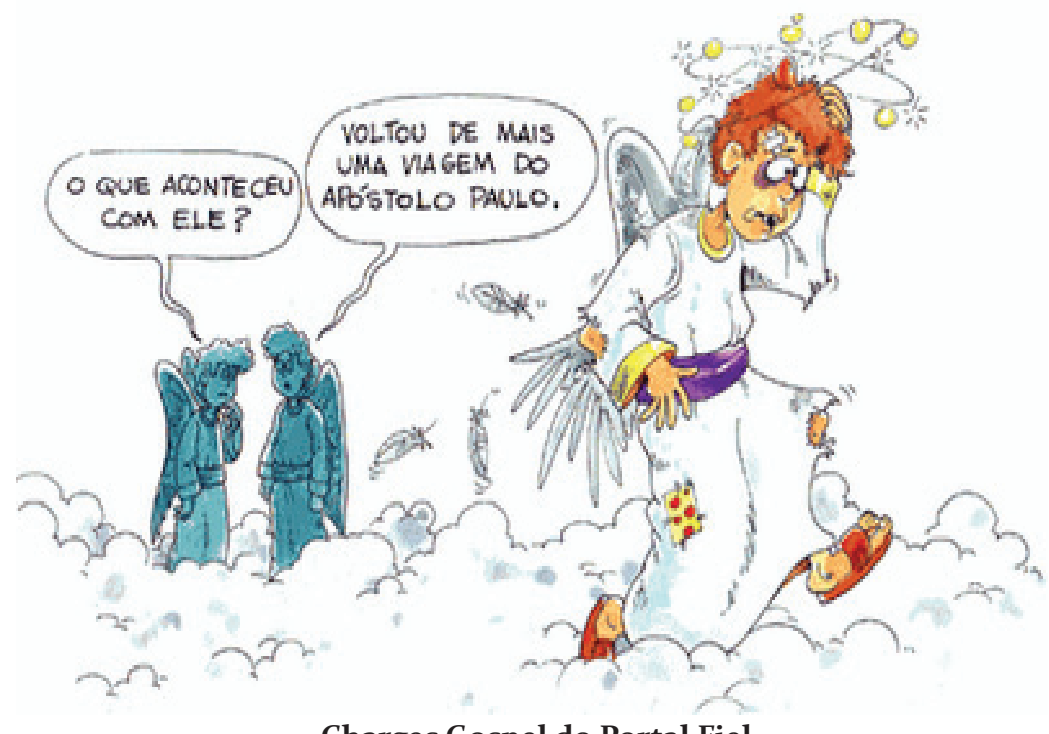

Charges Gospel do Portal Fiel

O Anjo do Apóstolo Paulo sofria muito, não era fácil ser anjo de alguém que era perseguido pelas autoridades romanas e que de acordo com II Coríntios 12:7, tinha um espinho na carne, que o esbofeteava sem parar para que ele não se exaltasse. Pela charge acima, sobrou espinho até para seu anjo da guarda!

Sobre o Apóstolo Pedro, e o episódio conhecido como a Negação de Pedro, no qual Pedro negou três vezes conhecer a Jesus, antes que o galo cantasse, parece não haver dúvida, uma vez que a exegese revela que todos os quatro Evangelhos relatam o ocorrido. Citamos apenas o relato de Mateus 26:33-35.

Disse-lhe Pedro: Ainda que sejas para todos uma pedra de tropeço, nunca o serás para mim. Declarou-lhe Jesus: Em verdade te digo que esta noite, antes de cantar o galo, três vezes me negarás. Replicou-lhe Pedro: Ainda que me seja necessário morrer contigo, de nenhum modo te negarei. Todos os discípulos disseram o mesmo. (Bíblia na Versão Almeida Revista e Atualizada, 1999, p.53, negrito nosso) 


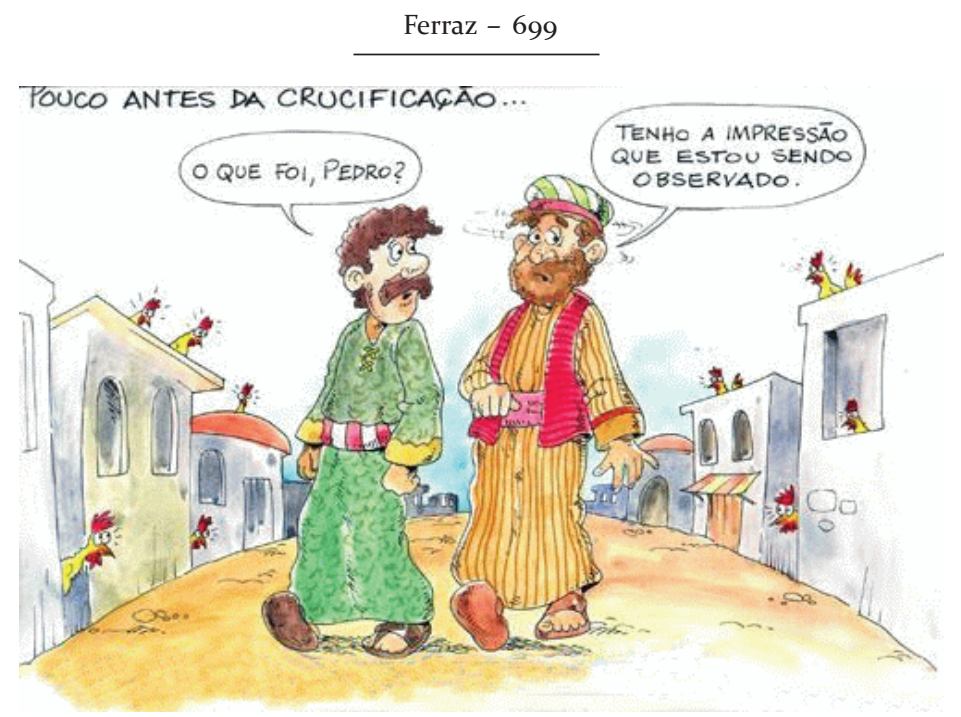

O Apóstolo Pedro, medroso e mentiroso, foi, posteriormente, transformado no primeiro Papa da Igreja, cujo pontificado ocorreu entre 30 e 67, enquanto Judas que traiu Jesus com um beijo, é até hoje malhado ou queimado no Sábado de Aleluia. Que pena que o Apóstolo Pedro não conhecia o Poema Tecendo a Manhã de João Cabral de Melo Neto:

Tecendo a Manhã

Um galo sozinho não tece uma manhã:

ele precisará sempre de outros galos.

De um que apanhe esse grito que ele e o lance a outro; de um outro galo que apanhe o grito de um galo antes e o lance a outro; e de outros galos que com muitos outros galos se cruzem os fios de sol de seus gritos de galo, para que a manhã, desde uma teia tênue, se vá tecendo, entre todos os galos.

Em Êxodo, Capítulos 7 a 12 são registradas as dez pragas que YHVH envia sobre o Egito para que Faraó libere os judeus que são escravos ali. As dez pragas são:

1) águas transformada em sangue; 2) a invasão de rãs; 3) a invasão de piolhos 4) a invasão de moscas; 5) peste nos animais; 6) úlceras; 7) saraiva; 8) invasão de gafanhotos; 9) trevas; 10) a morte dos primogênitos. Oras, depois de tudo isto havia necessidade de Moisés fazer alguma a pergunta abaixo a Faraó?: 


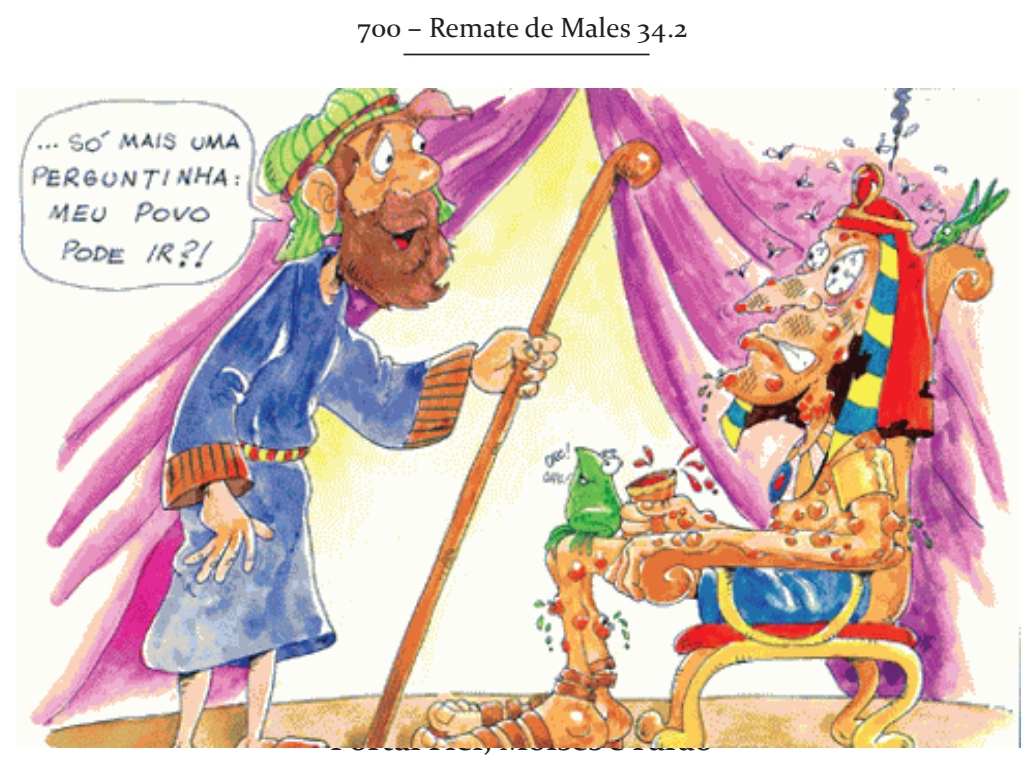

Os gaúchos e seu incrível senso de humor parodiaram o famoso Salmo 23:

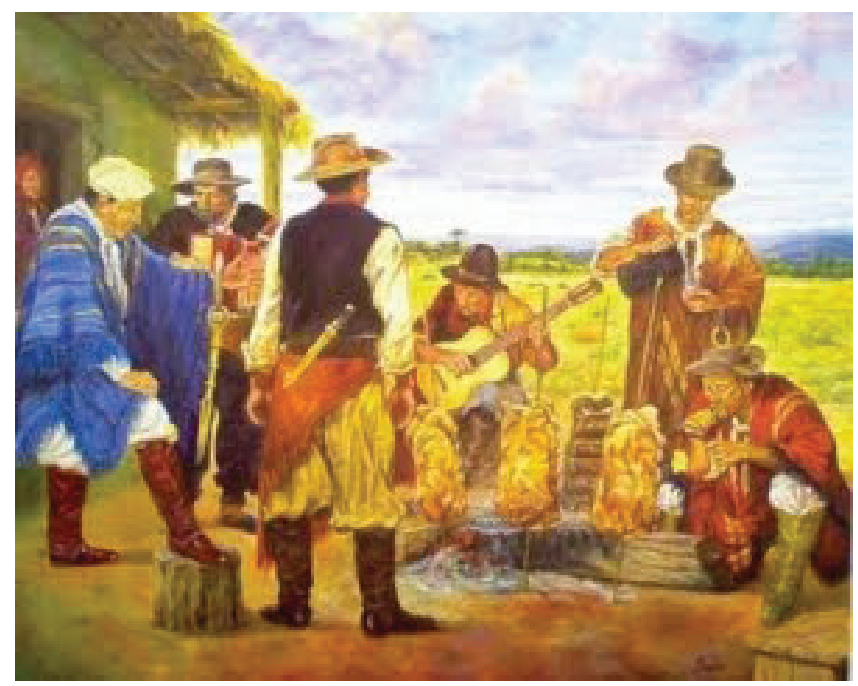

Salmo 23-Gaúcho

O Patrão é meu Pastor, nada vai me faltar.

Tu me faz tirar uma céstia nas coxilhas, pega minhas rédeas e me leva, devagarito, por águas tranquilas.

Esfria a minha alma, e de lambuja, me dirige por pagos de justiça, por amor do teu nome.

Ainda que a bala passasse rente as crinas deste vivente, não 
temeria mal algum, porque tu tá sempre do meu lado; a tua bombacha e as tuas espóras me aproxegam.

- Me prepara uma bóia, loca de especial, na frente dos home, derrama esse óleo na minha cabeça, e minha cuia vai se enche.

- Bah! - Bem capaz que tua bondade e a tua misericórdia não irá vaguear pelos dias deste indio véio, $\mathrm{e}$ assim, vou me encostar na casa do Patrão

por longos dias.

E ser chargista cristão e gaúcho é um humor duplo. Observamos como fica São João 14: 27 - Deixe-vos a paz, a minha paz vos dou; não vo-la dou como o mundo a dá. Não se turbe o vosso coração, nem se atemorize - no Evangelho segundo o Gaúcho.

\section{A vida no mundo é só entrevero e alvoroço mas quem vive com Cristo, anda mais tranquilito que água de poço.}

\section{João $14: 27$}
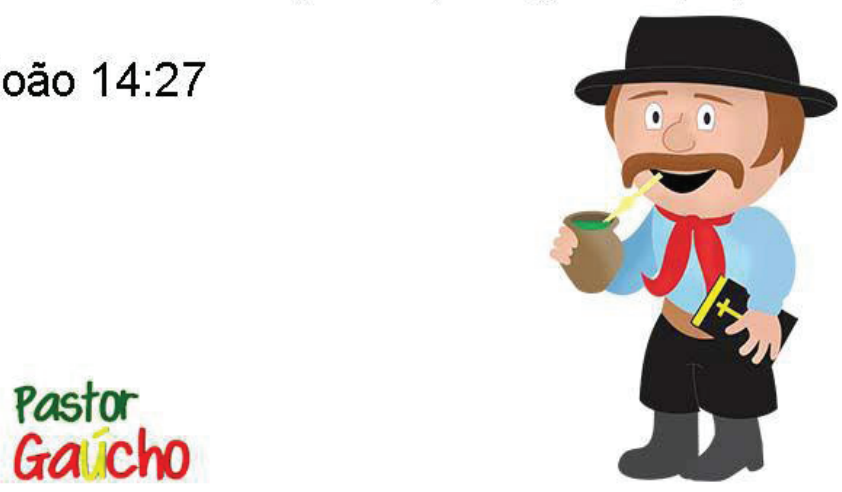

Site nação jovem

Somos tão paródicos, os brasileiros, e em especial minha terra Santa Catarina, que conseguimos ter nosso próprio Messias, nascido não em Belém, mas em Indaial, pequena cidade localizada no Médio vale do Itajaí. Pois é ali entre descendentes de alemãs, italianos e poloneses, com ancestrais tapajós e carijós, que nasceu a paródia do Messias conhecido como Inri Cristo. 


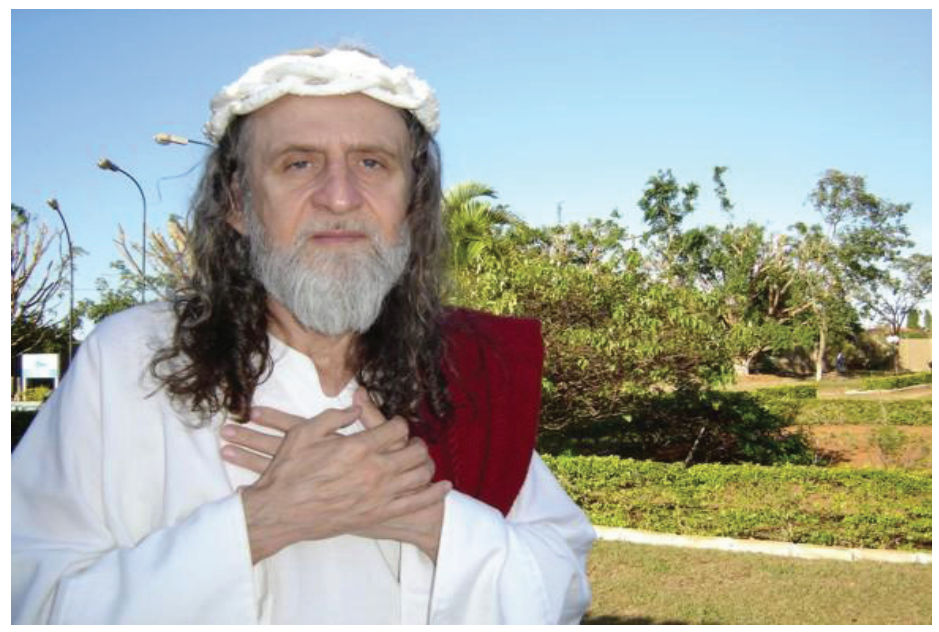

Inri Cristo

Fundador da SOUST - Suprema Ordem Universal da Santíssima Trindade, conhecida como Nova Ordem Mística instituída por INRI CRISTO em 28/02/1982, com sede em Brasília. O Messias de Indaial, que vive aparecendo na mídia televisiva e entrando em muitas polêmicas com padre Quevedo, é considerado por muitos como louco, por alguns, como Santo e Profeta inspirado e por outros como excêntrico inofensivo e pela articulista como figura folclórica. Ele também tem uma discípula amada: Analgiza Magdalena.

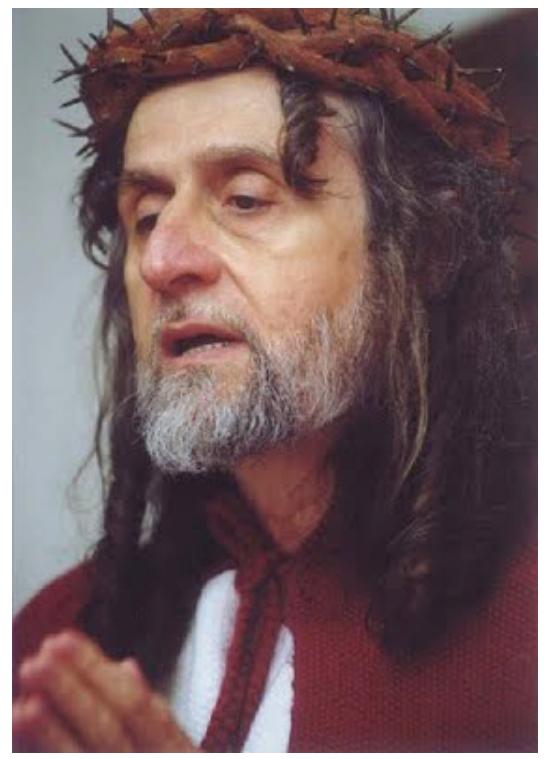

Inri Cristo 
Inri já tem verbete na Wikipedia, a qual reproduzimos alguns trechos abaixo:

\begin{abstract}
Álvaro Inri Cristo Thais (Indaial,22 de março de 1948) é um líder religioso brasileiro que proclama ser a reencarnação de Jesus Cristo. Inri já apareceu em diversos programas de TV, rádio e podcasts, como Programa Silvio Santos, Programa do Jô, Programa do Ratinho, Super Pop, O Estranho Mundo de Zé do Caixão, Pânico na TV, CQC, QG Podcast (onde debate com outras pessoas, como Padre Quevedo e Toninho do Diabo) e Agora é Tarde.

Inri Cristo fundou a instituição "Suprema Ordem Universal da Santíssima Trindade" (SOUST) em 28 de fevereiro de 1982 após ter praticado o "Ato Libertário" dentro da Catedral Metropolitana de Belém. A SOUST estava provisoriamente situada em Curitiba, até se instalar definitivamente em Brasília no ano de 2006, local onde ele afirma ser a "Nova Jerusalém" do Apocalipse 21.

Inri Cristo esteve sempre cercado de muita polêmica e já deu muitas entrevistas. Foi criado por um casal de teuto-brasileiros Magdalena e Wilhelm Thais. Seu sobrenome Thais é fruto de um erro de grafia do original alemão Theiss.

Em 1979, afirma ter tido a revelação de sua verdadeira identidade, após ter feito jejum durante alguns dias em Santiago, no Chile. Antes disso, era conhecido como Iuri de Nostradamus, nome que adotou como vidente e conselheiro.

Em seguida à suposta revelação, passou a pregar sua doutrina, tendo visitado vários países da América Latina e Europa. Foi expulso da Inglaterra e dos EUA, mas foi acolhido na França por nove meses. De volta ao Brasil, após anos de processo por falsidade ideológica, o Tribunal de Justiça do Estado do Paraná reconheceu o seu direito de usar o nome Inri Cristo junto a seu nome de batismo em todos os seus documentos.
\end{abstract}

A adoção do nome "Inri" aconteceu depois que um jornal mexicano o publicou. Isto seria considerado o primeiro sinal, depois da revelação em Santiago, de que ele seria o Cristo "reencarnado". INRI, acrônimo de "Jesus de Nazaré Rei dos Judeus" seria, segundo a revelação, o novo nome do Cristo retornado.

Em Portugal, Inri Cristo apareceu no programa "Noites Marcianas", quando era apresentado por Carlos Cruz. Atualmente, divulga sua doutrina através da mídia (principalmente internet e televisão, nesta, onde debate com outros líderes religiosos e aparece em programas de entrevista e humor (...). Fora esta divulgação, vai a universidades dar palestras a alunos, como já aconteceu por diversas vezes em várias cidades do Brasil, a saber Faculdade de Comunicação da UnB (Brasília 27 de novembro de 2007), UFPR (Curitiba, 17 de maio de 2000), Faculdade de Jornalismo da Universidade TUIUTI (Curitiba, 30 de abril de 1998 e 14 de novembro de 2001), SPEI, FAAP (São Paulo, 29 de outubro de 2003), USP (São Paulo, 4 de maio de 2004), Faculdade de Enfermagem da Universidade UNIANDRADE (Curitiba, 15 de setembro de 2004), UNISO (São Paulo, 29 de outubro de 2004), Faculdade de Jornalismo da UNIBRASIL (Curitiba/PR, 17 de maio de 2005), Faculdade de Filosofia de La Paz, Grand École Polytechnique de Paris.

Inri procura aproximar-se do público mais jovem criando versões "místicas" de hits de artistas populares, como Justin Bieber, Britney Spears, entre muitos outros. Os clips, sempre cantados pelas “inriquetes". 
Se alguém tem dúvida da existência do Messias, agora não há mais problemas, temos a própria identidade emitida pelo Estado de Santa Catarina com assinatura e tudo:

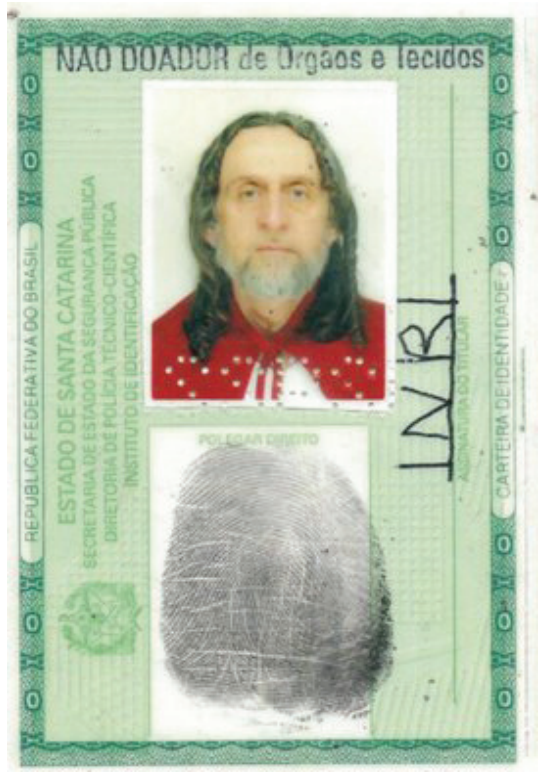

No romance O nome da Rosa (1983) de Umberto Eco, o monge Jorge de Burgos tenta manter em segredo o suposto segundo livro perdido de Aristóteles porque trataria do riso, escondido dentro da Biblioteca de uma Abadia Medieval. Todos que tentavam ler o livro morriam.

O fanático Jorge de Burgos queria destruir o livro de Aristóteles porque segundo ele o livro apresentava uma epifânia do mundo ao avesso e o riso possuía uma fagulha luciferina. Ele acaba comendo quase o Aristóteles inteiro, uma vez que rasga e engole as páginas envenenadas do livro. Morre rindo por acreditar que assim havia se tornado o túmulo do riso. Ele estava errado. A fagulha luciferina do riso não se apagou e entrou dentro daquilo que ele mais temia: a Teologia.

O que Jorge de Burgos, os Pais da Igreja, os Padres do Deserto e todos os teólogos medievais que condenavam o riso diriam dos Ministros do Riso que atuam em São Paulo desde 2006, que levam a mensagem de Jesus através do Riso e da graça? São artistas que sabem representar, dançar, cantar, e fazem humor para levar a mensagem de Jesus adiante. São pregadores palhaços que apresentam sua versão bem humorada dos Evangelhos em praças, hospitais e escolas. Eles se inspiraram nos Doutores da Alegria, nos Doutores do Riso e no Cirque do Soleil. Vale a pena visitar a páginas destes pregadores alegres que trazem Boas Novas repletas de leveza! 
Os Pais do Deserto, os Pais da Igreja, e o fanático Jorge de Burgos estavam errados: Neste mundo de tantas tragédias, injustiças, só o humor salva.!

\section{REFERÊNCIAS BIBLIOGRÁFICAS}

BERGSON, Henri. O riso: ensaio sobre a significação do cômico. Rio de Janeiro: Zarar, 1980.

BÍBLIA. Versão Nova Tradução na Linguagem de Hoje (NTLH). Disponível em http:// biblia.com.br/nova-traducao-linguagem-hoje/. Consultado em 14/05/2013.

BIBLIA ON LINE. Disponível em http://www.bibliaonline.com.br/acf/jo/14. Consultado em 04/06/2013.

CHAIN, Isa Gomes da Cunha. O Diabo nos porões das caravelas. Juiz de Fora; EUFJF, 2003.

D’ANGELLI, Concetta \& PADUANO, Guido. O Cômico. Trad. Caetano Waldrigues Galindo. Curitiba: Editora da UFPR, 2007.

DUARTE, Lélia Parreira. Ironia e Humor na Literatura. Belo Hortizonte: PUC Minas, 2006.

ECO, Umberto. O Nome da Rosa. Trad. Aurora Fornoni Bernardini. Rio de Janeiro: Record, 1986.

FERRAZ, Salma. As Malasartes de Lúcifer. Londrina: EDUEL, 2012.

GUERRA, Felipe de Monte. O Diabo também é brasileiro: a figura de Satanás no Cinema Nacional. São Paulo: Universidade Anhembi, 2011< Dissertação de Mestrado

MINOIS, Georges. História do Riso e do Escárnio. Trad. Maria Elena O. Ortiz. Assunção. São Paulo: Unesp, 2033.

TEIXEIRA, Duda. A maldição da múmia. In. Revista Veja. São Paulo: Abril, 13 de março de 2013, n. 11, Ano 46, Edição 2312.

Sites -vídeos

Eliseu o Estúpido profeta careca. Disponível em http://www.youtube.com/ watch?v=EwZ3RBAtL2E, consultado em 13/05/2013.

Sites - Charges

Anjo do Apóstolo Paulo. Disponível em http://mfcmamonas.no.comunidades.net/ index.php?pagina=1084261305 04 e no site http://www.portalfiel.com.br/charges. php?id=119-viagem-do-apostolo-paulo-biblia.html, sem identificação de autoria, consultado em 14/05/2013. 
BOTELHO, Jasiel. Porque Deus é Humor. Disponível em http://jasielbotelho.blogspot. com.br, consultado em 14/05/2013.

BRIZOTTI, Alan. Genizah. Disponível em http://www.genizahvirtual.com/2009/10/ pato-donald-gente-ri-dos-pentecostais.html, consultado em 14/05/2013.

FARELL, Paul. Illustrated Stories from the Bible - that they won't tell you in Sunday School. Disponivel em http:// outrasverdadesinconvenientes.blogspot.com.br/2011/05/os-grandes-exemplos-deamor-e-bondade 1550.html, consultado em 14/05/2013.

Filhotes de Cristo. Charge de Moisés e do Faraó do Egito. Disponível em http://www. filhotesdecristo.xpg.com.br/imagens2.htm, consultado em 14/05/2013.

Jesus sorrindo OK. Disponível em http://agnussanctus.blogspot.com.br/2012/o7/jesuse-nossa-alegria-verdadeira.html, consultado em 15/05/2013.

Inri Cristo. Disponível em http://3.bp.blogspot.com/-EQxp8AIxZSI/Tuty7ErCqqI/ AAAAAAAAK8k/2pgsR4XiYSA/s16oo/inri-cristo-0o1.jpg, consultado em 04/06/2013.

NICOLAU, Leonardo. Só risos abençoados - Charges de Jesus curtindo e Paulo enviado email aos Coríntios. Disponível em http://leonardonico.blogspot.com.

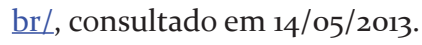

NOGUEIRA, Tiago. Pouco antes da Crucifixão. Disponível em http://cenaculouniversal. wordpress.com/2010/09/27/pouco-antes-da-crucificacao/, consultado em 14/05/2013.

Palavras mais pronunciadas numa Igreja x Motel. Disponível em http://www. tirinhasmemes.net/palavras-mais-pronunciadas-numa-igreja-evangelica-vs-nummotel-736.html, consultado em 13/05/2013.

Pastor Gaúcho. Disponível em http://nacaojovemanapolis.com/wp-content/ uploads/2013/o1/pastor-ga\%C $3 \%$ BAcho.jpg. Consultado em 04/o6/2013.

Portal Fiel. Charge do Deputado Marcos Feliciano. Disponível em http://www. portalfiel.com.br/charges.php, consultado em 07/05/2013.

Profeta Jonas. Disponível em http://www.infiltradosnomundo.com.br/2012/11/jonasdesobediente-mas-usado.html, consultado em 17/05/2013.

RANGEL, Alex. Ministros do Riso. Disponível em http://ministrosdoriso.blogspot.com. br/, consultado em 14/05/2013

Resposta Cristã. Disponível em http://respostacristagratuita.blogspot.com.br/2012/12/ como-posso-resumir-o-livro-de-genesis.html, consultado em 14/05/2013.

Top 5 do Capeta. Disponível em http://www.queronaao.com/2012/05/top-5-fatos-sobreo-capeta.html, consultado em 13/05/2013. 
Tudo com Jesus - Charges Cristãs. Disponível em http://mfcmamonas.no.comunidades. net/index.php?pagina=1084261305_04, Consultado em 07/05/2013

Vilmar, Antonio. Blog do Antonio Vilmar. Disponível em http://wilmarmensagens. blogspot.com.br/2012/o3/jaco-o-enganador-transformado-em-israel.html, consultado em 14/05/2013. 